\title{
Europerikelen: consequenties van uittreding uit de euro voor in euro's luidende verbintenissen
}

\author{
Prof. mr. W.A.K. Rank*
}

\begin{abstract}
1 Inleiding
In de praktijk komt regelmatig de vraag op of een Nederlandse leninggever een valutarisico loopt indien hij uitzettingen luidende in euro's heeft in een ander Euroland en dat Euroland op enig moment zou besluiten uit de euro te stappen. Die vraag rijst evenzeer indien dat Euroland zou worden gedwongen de eurozone te verlaten. Het gaat daarbij meer in het bijzonder om de vraag of een uitzetting die thans in euro's luidt, na een (vrijwillige of gedwongen) uittreding van een dergelijk Euroland uit de euro zou kunnen komen te luiden in een door een dergelijk land nieuw in te voeren vervangende valuta of dat de schuld gewoon een schuld in euro's blijft. In het eerste geval zou de leninggever een valutarisico lopen als de nieuw geïntroduceerde valuta na haar invoering in waarde daalt ten opzichte van de euro. In het tweede geval is er slechts het altijd al aanwezige risico van non-betaling, maar geen additioneel valutarisico. In verband met de mogelijke uittreding van Griekenland uit de eurozone was deze vraag in 2011/2012 enorm actueel. Dit blijkt vooral uit de schier onafzienbare reeks nieuwsbrieven en rapporten van advocaten, denktanks en ban-
\end{abstract}

Prof. mr. W.A.K. Rank is hoogleraar Financieel Recht aan de Universiteit Leiden en advocaat te Amsterdam. ken die in die periode over dit onderwerp zijn gepubliceerd. ${ }^{1}$ Er zijn destijds - en zelfs voordat de crisis zich aandiende ook wel wetenschappelijke publicaties over deze problematiek verschenen, maar vergeleken bij de vele in het commerciële circuit gepubliceerde bijdragen gaat het hier toch om een

1. Te noemen zijn in dit verband: Allen \& Overy, The Euro and Currency Unions, oktober 2011, M.G. Arghyrou \& J.D. Toukalas, The Option of Last Resort: A Two-Currency EMU, Cardiff Economics Working Papers 2010/14, Ashurst, International Contracts and the Eurozone Crisis (Securities and Derivatives Briefing), januari 2012, Ph. Athanassiou, Withdrawal and Expulsion from the EU and EMU; Some Reflections (ECB Legal Working Paper Series, no. 10), december 2009, W. Boonstra, Breaking Up the Eurozone: Blessing or Disaster? (Rabobank Working Paper Series, 2010/01), oktober 2010, W. Buiter \& E. Rahbari, The Future of the Euro Area: Fiscal Union, Break-up or Blundering: Towards a 'You Break It, You Own It Europe', Citi Global Economics View 9 september 2011, Clifford Chance, The Eurozone Crisis and Exchange Controls (Briefing Note), juli 2012, Clifford Chance, The Eurozone Crisis and Loan Agreements - The Dutch Law Perspective (Briefing Note), februari 2012, Clifford Chance, The Eurozone Crisis and Derivatives (Briefing Note), januari 2012, Clifford Chance, The Eurozone Crisis and Eurobond Documentation (Briefing Note), november 2011, De Brauw Blackstone Westbroek, Eurozone Crisis: Preparation for a Break-up, Legal Alert 7 december 2011, De Brauw Blackstone Westbroek, Eurocrisis - wat betekent het voor uw onderneming?/Euro Crisis - How Does It Impact Your Business?, Legal Alerts 19 oktober 2011/25 oktober 2011, E. Dor, Leaving the Euro Zone: A User's Guide (IESEG Working Paper Series, 2011-ECO-06), Dorsey, The Eurozone Crisis - Practical Implications for Clients, Attorney Articles 2 juli 2012, Field Fisher Waterhouse, The Eurozone Crisis and Financial Transactions, A Comprehensive Guide, mei 2012, Herbert Smith, Potential Eurozone Breakup: Questions and Answers, november 2011, Herbert Smith, Eurozone Crisis - The Corporate Perspective, januari 2012, Houthoff Buruma, How to Limit Your Risks in the Event of a Eurozone Break-up, News Update januari 2012, King \& Spalding, Withdrawal from the Euro: The Effect on Existing Contracts, Energy Newsletter 1 juni 2012, McDermott Will \& Emery, The Euro Crisis: Impacts on Cross-border Contracts, 14 juni 2012, McGuire Woods, The Euro Zone Crisis and Commercial Contracts: What If...?, Legal Update 13 februari 2012, Morrison \& Foerster, A Euro Break-up: Impact on Financial Documentation, News Bulletin 19 januari 2012, Nomura, Currency Risk in a Eurozone Break-up - Legal Aspects, 18 november 2011, Ch. Proctor, The Greek Crisis and the Euro - A Tipping Point?, Edwards Angell Palmer \& Dodge, Client Advisory, juni 2011, Rabobank, Als de euro zou vallen, Themabericht 2011/19, Reed Smith, Euro Contingency Planning: Why It Is Necessary Now, What It Should Cover and How We Can Help, Reed Smith Client Alerts 22 juni 2012, Slaughter and May, Euro Breakup/Fragmentation - Impact on Financing Documentation (Briefing), december 2011, Slaughter and May, The Eurozone Crisis. An Indicative Approach to Contingency Planning (Briefing), december 2011 en UBS, Euro Break-up - The Consequences, 6 september 2011. 


\section{Maandblad}

bescheiden aantal. ${ }^{2} \mathrm{Op}$ dit moment is een mogelijk uittreden van een Euroland uit de eurozone of een opsplitsing van de euro geen onderwerp van publiek debat. Alle aandacht gaat uit naar het uittreden van het Verenigd Koninkrijk uit de EU. Dat neemt echter niet weg dat de vraag naar de consequenties van uittreding uit of opsplitsing van de euro voor de continuïteit van contracten in de praktijk nog wel degelijk speelt.

In dit artikel gaat het om de consequenties van uittreding van een Euroland uit de euro voor in euro's luidende verbintenissen van ingezetenen van het desbetreffende land. Het gaat daarbij in het bijzonder om de vraag of een verbintenis die thans in euro's luidt na uittreding zou kunnen komen te luiden in een door het desbetreffende land nieuw in te voeren vervangende valuta of dat de schuld gewoon een schuld in euro's blijft. Daarbij zal de nadruk liggen op de wijze waarop de relevante rekeneenheid in een dergelijk scenario door de rechter zal (moeten) worden bepaald. Voorts komt aan de orde hoe contractspartijen kunnen proberen te voorkomen dat de verbintenis zal worden aangemerkt als een verbintenis luidende in de nieuw geïntroduceerde vervangende valuta. ${ }^{3}$ In dit verband wordt ervan uitgegaan dat in de leningsdocumentatie niet is voorzien in continuiteitsclausules, bepalingen over de identiteit van de valuta waarin is gecontracteerd of bepalingen over omrekening en afronding voor het geval dat later geconcludeerd zou worden dat de relevante rekeneenheid niet de euro is, maar een daarvoor in de plaats getreden valuta. Voorts wordt ervan uitgegaan dat de wetgeving van het land van de nieuw geïntroduceerde valuta zal voorzien in een omrekeningsverhouding tussen de euro en de nieuw geïntroduceerde vervangende valuta en in een verplichte redenominatie van verbintenissen luidende in euro's in verbintenissen luidende in de nieuwe valuta, al dan niet beperkt tot verbintenissen van ingezetenen of verbintenissen beheerst door het recht van het desbetreffende land, maar niet in regels ter nadere bepaling van de identiteit van de contractvaluta. Bij een ordelijk verlopende uittreding van één of meer landen uit de euro zal waarschijnlijk wel zijdens de EU worden voorzien in regelgeving om de continuïteit van contracten te waarborgen.

2. Zie o.m. H.C. Scott, When the Euro Falls Apart, International Finance 1998, p. 207-228, Ch. Proctor, Mann on the Legal Aspect of Money, Oxford: Oxford University Press 2005, hoofdstuk 32 'Withdrawal from the Eurozone', p. 771-792, G. Thieffry, Not So Unthinkable - The Break-up of European Monetary Union, International Financial Law Review 2005, afl. 7, p. 15-17, B. Eichengreen, The Breakup of the Euro Area, in: A. Alesina \& F. Giavazzi (red.), Europe and the Euro, Chicago: University of Chicago Press 2010, p. 11-51, G. Thieffry, Thinking the Probable: The Break-up of Monetary Union, Journal of International Banking Law and Regulation 2011, afl. 3, p. 103-104, Ch. Proctor, The Euro-fragmentation and the Financial Markets, Capital Markets Law Journal 2011, afl. 6, p. 5-28, V.P.G. de Serière, Contractuele aspecten van een Eurozone crisis, Ondernemingsrecht 2012, afl. 7, p. 279-286 en C.P. Hooft, De contractuele gevolgen van een eurodesintegratie, O\&F 2012, afl. 3, p. 12-25.

3. Deze onderwerpen worden ook besproken door De Serière 2012 en Hooft 2012. Deze beide auteurs benaderen het probleem van mogelijke redenominatie van verbintenissen in euro's vooral als een opzichzelfstaand en uniek fenomeen, terwijl in het onderhavige artikel wordt geprobeerd het probleem te benaderen als een vraagstuk dat zich, zij het in een andere gedaante en context, al eerder heeft voorgedaan.
De geschiedenis leert echter dat het inperken van de territoriale reikwijdte van een geldstelsel of het oplossen van een enkele geldeenheid in twee of meer afzonderlijke geldeenheden meestal niet op een ordelijke wijze verloopt. Bovendien zullen er nog altijd problemen kunnen ontstaan met betrekking tot contracten in euro's beheerst door het recht van derde landen. Het zal dan steeds aan de bevoegde rechter zijn om te bepalen of de verbintenis een schuld in euro's is gebleven of dat de verbintenis, met alle risico's van dien, in de nieuw geïntroduceerde vervangende valuta is komen te luiden.

De vragen die zich bij uittreding uit de euro manifesteren, zijn ook aan de orde geweest bij de invoering van de euro aan het eind van de vorige eeuw. Weliswaar ging het toen om omzetting van de nationale valuta in euro's en gaat het nu om het omgekeerde, maar in beide gevallen betreft het de eventuele redenominatie van verbintenissen in een nieuwe geldeenheid. Sinds 1 januari 1999 is de euro de officiële geldeenheid van de op dat moment aan de derde fase van de Economische en Monetaire Unie (EMU) deelnemende EU-lidstaten (België, Duitsland, Finland, Frankrijk, Ierland, Italië, Luxemburg, Nederland, Oostenrijk, Portugal en Spanje). Nadien is zij ook als zodanig ingevoerd in een aantal andere EU-lidstaten (in Griekenland op 1 januari 2002, in Slovenië op 1 januari 2007, in Cyprus en Malta op 1 januari 2008, in Slowakije op 1 januari 2009, in Estland op 1 januari 2011, in Letland op 1 januari 2014 en in Litouwen op 1 januari 2015). Vorderingen en schulden luidende in de nationale valuta werden vervolgens steeds na verloop van een overgangsperiode na de invoering als officiële geldeenheid geconverteerd in euro's volgens de officiële omrekeningsverhouding. Introductie van de euro als nieuwe geldeenheid, vaststelling van de omrekeningskoersen en redenominatie van in de nationale valuta luidende verbintenissen in verbintenissen in euro's hebben plaatsgevonden op basis van een drietal door de Raad vastgestelde verordeningen. ${ }^{4}$ Ofschoon er derhalve sprake was van een communautaire juridische basis voor de invoering van de euro, heeft deze invoering niettemin voor de nodige hoofdbrekens gezorgd, niet alleen op het punt van de continuïteit van contracten, maar ook op het punt van pensioenen, effectenverkeer, derivaten, referentierentes, vennootschaps- en rechtspersonenrecht, fiscaliteit en in internationaal monetair verband. Een en ander heeft destijds de nodige pennen in beweging

4. Het betreft hier Verordening (EG) $1103 / 97$ van de Raad van 17 juni 1997 over enkele bepalingen betreffende de invoering van de euro, PbEG 19 juni 1997, L 162/1, zoals laatstelijk gewijzigd bij Verordening (EG) 2595/2000 van de Raad van 27 november 2000, PbEG 29 november 2000, L 300/1, Verordening (EG) 974/98 van de Raad van 3 mei 1998 over de invoering van de euro, PbEG 11 mei 1998, L 139/1, zoals laatstelijk gewijzigd bij Verordening (EU) 827/2014 van de Raad van 23 juli 2014, PbEU 31 juli 2014, L 228/3 en Verordening (EG) 2866/98 van de Raad van 31 december 1998 over de omrekeningskoersen tussen de euro en de munteenheden van de lidstaten die de euro aannemen, PbEG 31 december 1998, L 359/1, zoals laatstelijk gewijzigd bij Verordening (EU) 851/2014 van de Raad van 23 juli 2014, PbEU 6 augustus 2014, L 233/21. 


\section{Maandblad}

gebracht. ${ }^{5}$ Zullen de problemen die zich bij de invoering van de euro hebben voorgedaan zich waarschijnlijk wederom voordoen bij uittreding uit de euro door één of meer Eurolanden, in de rede ligt dat de toentertijd gevonden oplossingen ook opnieuw bruikbaar zullen blijken te zijn.

Voordat op de hiervoor geschetste problematiek wordt ingegaan, zal eerst enige aandacht worden besteed aan de conflictenrechtelijke inbedding van de relevante vragen. Het zal immers verschil kunnen maken of de redenominatievraag moet worden beantwoord aan de hand van het recht van het uittredende Euroland of aan de hand van een ander recht. Vervolgens komt aan de orde de eerder in Nederland met betrekking tot de bepaling van een contractvaluta gewezen rechtspraak. Ofschoon deze rechtspraak betrekking heeft op andere situaties - ik noem in dit verband met name de zogenaamde Indische valutageschillen -, kan zij zeker als inspiratiebron voor de onderhavige kwesties dienen. Buiten beschouwing blijft de vraag of een Euroland überhaupt wel uit de euro kan stappen of uit de euro kan worden gezet. Ook de vraag naar de betekenis van eventuele door het uittredende Euroland uitgevaardigde deviezenmaatregelen blijft hier onbesproken. ${ }^{6}$

\section{Toepasselijk recht en bevoegde rechter}

Om de relevante vragen beter te kunnen duiden, lijkt het dienstig om te bezien tot welk statuut zij vanuit het perspectief van internationaal privaatrecht behoren. In dit verband dienen zich op voorhand twee mogelijke rechtsstelsels aan, te weten de lex monetae, het recht van (het land van uitgifte van) de valuta en de lex contractus, het recht dat van toepassing is op de overeenkomst. In beginsel bepaalt de bevoegde rechter aan de hand van het in zijn jurisdictie geldende internationaal pri-

5. Zie, wat de Nederlandse literatuur betreft, bijv. M. Bunicich (red.), De juridische aspecten van de euro, Deventer: Kluwer 1997, met bijdragen van diverse auteurs, en voorts W.A.K. Rank, Geld, geldschuld en betaling, Deventer: Kluwer 1996, p. 66 e.v., W.A.K. Rank, Invoering van de euro: juridische (on)mogelijkheden en (on)zekerheden, Bb 1996, p. 111-112, W.A.K. Rank, Komt de continuïteit van overeenkomsten in gevaar?, in: De komst van de euro en de gevolgen voor uw bedrijf, Amsterdam: RPMS 1996, p. 55 e.v., W.A.K. Rank, Juridische aspecten van de invoering van de euro als gemeenschappelijke Europese valuta, NTBR 1997, afl. 3, p. 54 e.v., B.J. Drijber, EG-Commissie stelt maatregelen voor in verband met de invoering van de euro, TVVS 1996, afl. 11, p. 316-318, A.F. Verdam, Invoering van de euro: gevolgen voor de bedrijfsjuridische praktijk, TVVS 1996, afl. 12, p. 340 e.v., S.A Boele, Civielrechtelijke vragen rond de invoering van de euro, NJB 1997, p. 237 e.v., S.A. Boele, Conversie van schuldtitels in euro: de Wet schuldredenominatie, TVVS 1998, afl. 8, p. 230-235, M. van Olffen, Eurowetgeving voor N.V.'s en B.V.'s, WPNR 2000/6420, p. 713-718, en de talloze artikelen van verschillende auteurs over verschillende aspecten van de invoering van de euro in respectievelijk Eurobulletin (Kluwer, 6x verschenen in 1997), Eurokoers (Nationaal Forum voor de introductie van de euro, 4x verschenen in 1996) en Nieuwsbrief EMU \& Euro (Samsom, 11x verschenen in 1996).

6. Zie hierover wel: De Serière 2012, p. 283. vaatrecht welk recht in een gegeven situatie van toepassing is. ${ }^{7}$ Het zal derhalve van het nationale internationaal privaatrecht van het forum afhangen welke aspecten van de introductie van een nieuwe geldeenheid worden beheerst door de lex monetae en welke door de lex contractus. Dat neemt niet weg dat er op dit punt over de gehele linie wel sprake is van een zekere consensus. Algemeen wordt aangenomen dat de lex monetae bepalend is voor de vervanging van een nationale geldeenheid door een nieuwe nationale geldeenheid, de daarbij in acht te nemen omrekeningskoers en de toekenning van de kwaliteit van wettig betaalmiddel aan bepaalde geldmiddelen. ${ }^{8}$ Evenzo is de heersende opvatting dat de lex contractus bepalend is voor de vraag of er sprake is van een nieuwe contractvaluta en of een overeenkomst bij vervanging van de contractvaluta door een andere contractvaluta ongewijzigd in stand kan blijven. Men denke in dit verband aan de vraag of vervanging van de bestaande contractvaluta door een nieuwe in bepaalde gevallen een beroep op overmacht of onvoorziene omstandigheden door de leningnemer rechtvaardigt. ${ }^{9}$ Diffuser ligt het met betrekking tot de vraag of de vervanging van een nationale geldeenheid door een nieuwe nationale geldeenheid consequenties heeft voor verbintenissen luidende in de valuta van het desbetreffende land en meer in het bijzonder of deze verbintenissen in de nieuwe valuta zouden moeten worden geredenomineerd. Betoogd zou kunnen worden dat dit een vraag betreft met betrekking tot de inhoud van de overeenkomst en daarmee een kwestie die wordt beheerst door de lex contractus. ${ }^{10}$ Betoogd zou echter ook kunnen worden dat het hier gaat om de vraag waar een valuta precies voor staat en daarmee om een kwestie die wordt beheerst door de lex monetae. De gedachte is dan dat het beginsel van monetaire soevereiniteit meebrengt dat alleen de wet van het land van een valuta de inhoud van die valuta kan bepalen en dat dit principe alleen overeind kan blijven als partijen die in die valuta contracteren zich voor wat betreft de normering van die valuta naar die wetgeving hebben te richten, ook wanneer de valuta in kwestie voor hen een vreemde valuta is. ${ }^{11}$

7. In grensoverschrijdende burgerlijke en handelszaken is in de EU de Brussel I-bis-Verordening (1215/2012), voorheen de Brussel I-Verordening (44/2001), bepalend voor de rechtsmacht van de rechter. In beginsel wordt de gedaagde opgeroepen voor het gerecht van de plaats waar hij woonplaats heeft (art. 4 lid 1 Brussel I-bis). Op grond van art. 25 Brussel I-bis kunnen partijen ervoor kiezen hun geschillen door middel van een forumkeuzebeding te onderwerpen aan de rechtsmacht van de gerechten van een bepaalde lidstaat.

8. Zie F.A. Mann, The Legal Aspect of Money, Oxford: Oxford University Press 1982, p. 267-274 en Proctor 2005, p. 227-353. Vgl. art. 147 lid 1 Zwitserse IPR-wet: 'Was unter einer Währung zu verstehen ist, bestimmt das Recht des Staates, dessen Währung in Frage steht.'

9. Zie Mann 1982, p. 100 e.v. en 256-261, Proctor 2005, p. 340 e.v., A. Nussbaum, Money in the Law, Brooklyn: The Foundation Press 1950, p. 461 e.v., Rank 1996, p. 20 en 63 e.v.; 1997, p. 35 e.v. Vgl. art. 147 lid 2 Zwitserse IPR-wet: 'Die Wirkungen einer Währung auf die Höhe einer Schuld unterstehen dem Recht, das auf die Schuld anwendbar ist.'

10. Vgl. art. 12 Verordening (EG) 593/2008 van het Europees Parlement en de Raad van 17 juni 2008 inzake het recht dat van toepassing is op verbintenissen uit overeenkomst (Rome I), PbEU 17 juni 2008, L 177/6.

11. Mann 1982, p. 267; Proctor 2005, p. 332-340. 


\section{Maandblad}

In de praktijk blijkt de vraag of vervanging van de nationale geldeenheid moet leiden tot redenominatie van in deze geldeenheid luidende verbintenissen meestal te worden beantwoord aan de hand van de lex contractus én de lex monetae in onderling verband en samenhang. ${ }^{12}$ Dat gaat in twee stappen. Eerst zal de bevoegde rechter op basis van de lex contractus bepalen of de valuta waarin de verbintenis is uitgedrukt de nieuw geïntroduceerde, vervangende geldeenheid is dan wel nog steeds de oorspronkelijke geldeenheid. Dit is een kwestie van uitleg van de overeenkomst. Vervolgens zal de rechter in de meeste gevallen op grond van de lex monetae beoordelen of verplichte redenominatie van in de oorspronkelijke rekeneenheid luidende verbintenissen moet plaatsvinden. Daarbij zal hij ofwel meteen opteren voor toepassing van de lex monetae, ofwel eerst opteren voor toepassing van de lex contractus en vervolgens via het op de overeenkomst toepasselijke recht weer uitkomen bij de lex monetae. Die tweestappenbenadering vindt in de meeste landen haar oorzaak in het tot de aldaar geldende wetgeving behorende nominaliteitsbeginsel, het beginsel dat een verbintenis tot betaling van een geldsom in beginsel moet worden voldaan naar haar nominale bedrag. ${ }^{13}$ Deze regel is weliswaar van contractenrechtelijke aard, maar belichaamt een verwijzing naar de lex monetae voor wat betreft de inhoud van de verbintenis en de in acht te nemen omrekeningskoers. ${ }^{14}$ Dat brengt mee dat redenominatie van verbintenissen luidende in de oorspronkelijke valuta in verbintenissen in de nieuwe geldeenheid in beginsel alleen dan niet aan de orde zal zijn, indien (a) de omzettingsvraag volgens het internationaal privaatrecht van het forum moet worden gekwalificeerd als een vraag die wordt beheerst door de lex contractus en (b) de lex contractus het nominaliteitsbeginsel niet kent en evenmin een bijzondere bepaling bevat die redenominatie van verbintenissen van ingezetenen of van verbintenissen beheerst door de lex contractus expliciet voorschrijft. De vraag of vervanging van de contractvaluta door een nieuwe contractvaluta een grond voor ontbinding of wijziging van de overeenkomst is, wordt in beginsel weer aan de hand van de lex contractus beoordeeld. Het hier geschetste beeld kan er overigens anders uitzien als de redenominatieregels van het uittredende land door de aangezochte rechter worden beschouwd als bijzondere bepalingen van dwingend recht, dat wil zeggen als bepalingen die altijd en overal bij voorrang moeten worden toegepast, ongeacht het recht dat de overeenkomst beheerst. Dat zal met name het geval zijn als deze bepalingen tot het recht van het forum behoren of tot het recht van het land waar de verbintenis moet

12. Zie Rank 1996, p. 65-66 en 119-120; 1997, p. 36-38.

13. Zie voor Nederland art. 6:111 BW, waarover uitvoerig: Rank 1996, p. 115 e.v.

14. Zie voor Nederland MvA II, Parl. Gesch. BW Boek 6, p. 457, en Rank 1996, p. 65-66 en 119-120; 1997, p. 36-38. worden nagekomen (de lex loci solutionis). ${ }^{15}$ In die gevallen zal, ook indien de lex contractus niet in redenominatie voorziet, toch redenominatie plaatsvinden.

Is de rechter van het uittredende Euroland de bevoegde rechter en wordt de verbintenis beheerst door het recht van het uittredende Euroland, dan is het aan deze rechter om op basis van zijn nationale recht te bepalen welke rekeneenheid aard en omvang van de verbintenis bepaalt: de euro of de daarvoor in de plaats getreden nieuwe nationale valuta. Komt deze rechter tot de conclusie dat de contractvaluta de nieuwe valuta van het uittredende Euroland is, dan lijdt het geen twijfel dat het bedrag van de verbintenis zoals dat in euro's luidt door deze rechter zal worden omgezet in een bedrag in de nieuwe munt, waarbij wordt omgerekend volgens de bij de invoering van de nieuwe munt vastgestelde koers. De rechter past dan eenvoudigweg de redenominatieregels van zijn eigen jurisdictie toe. Het doet er in deze constellatie niet zoveel toe of de conversievraag volgens het internationaal privaatrecht van het forum moet worden gezien als een vraag die wordt beheerst door de lex monetae - het recht van (het land van) de valuta - of door de lex contractus. De lex monetae en de lex contractus lopen in dit geval immers samen en behoren bovendien tot de lex fori. Is de rechter van het uittredende Euroland de bevoegde rechter en wordt de verbintenis beheerst door Nederlands recht of het recht van een ander EU-land of een derde land, dan is het aan deze rechter om eerst op basis van het op de overeenkomst toepasselijke recht te bepalen welke rekeneenheid aard en omvang van de verbintenis bepaalt: de euro of de daarvoor in de plaats getreden nieuwe nationale valuta. Komt deze rechter tot de conclusie dat de contractvaluta de nieuwe valuta van het uittredende Euroland is, dan ligt het in de rede dat ook in dit geval het bedrag van de verbintenis zoals dat in euro's luidde door deze rechter zal worden omgezet in een bedrag in de nieuwe munt, waarbij wordt omgerekend volgens de bij de invoering van de nieuwe munt vastgestelde koers. Indien de lex contractus zich tegen een dergelijke redenominatie zou verzetten, zal deze rechter met een beroep op art. 9 van de Rome I-Verordening (Rome I) de lex contractus kunnen passeren en de redenominatieregels van zijn eigen jurisdictie bij voorrang kunnen toepassen, omdat deze regels naar het recht van zijn eigen jurisdictie zullen kwalificeren als bepalingen van bijzonder dwingend recht in de zin van dit artikel.

Is de Nederlandse rechter of de rechter van een ander EU-land of een derde land de bevoegde rechter en wordt de verbintenis beheerst door het recht van het uittredende Euroland, dan zal de rechter ongetwijfeld geneigd zijn de overeenkomst zo uit te

15. Zie voor de toepassing van bepalingen van bijzonder dwingend recht art. 9 Verordening (EG) 593/2008 van het Europees Parlement en de Raad van 17 juni 2008 inzake het recht dat van toepassing is op verbintenissen uit overeenkomst (Rome I), PbEU 17 juni 2008, L 177/6. Zie ook art. 12 lid 2 Rome I, volgens welke bepaling ten aanzien van de wijze van nakoming rekening wordt gehouden met het recht van het land van de plaats van nakoming. Zie voor de Nederlandse regels inzake de plaats van betaling van geldschulden art. 6:115-118 BW. Deze regels bestempelen geldschulden tot brengschulden. 


\section{Maandblad}

leggen dat de euro de contractvaluta blijft. Waarschijnlijk zal hij uiteindelijk echter toch geen andere keus hebben dan een beroep op redenominatie te honoreren, dit omdat de lex contractus nu eenmaal tot redenominatie verplicht. Is de Nederlandse rechter of de rechter van een ander EU-land of een derde land de bevoegde rechter en wordt de verbintenis beheerst door Nederlands recht of het recht van een ander EU-land of een derde land en niet door het recht van het uittredende Euroland, dan zal deze rechter aan de hand van het op de overeenkomst toepasselijke recht hebben vast te stellen welke valuta als de contractvaluta dient te worden aangemerkt. In dat geval is er een gerede kans dat de rechter tot de slotsom zal komen dat de relevante rekeneenheid nog steeds de euro is. De consequentie daarvan is dat men aan redenominatie dan niet meer toekomt en dat de verbintenis gewoon naar haar nominale bedrag in euro's moet worden betaald. Aldus bezien is vaststelling van de relevante rekeneenheid door de rechter uiteindelijk bepalend voor de vraag of de invoering van een nieuwe valuta in een Euroland consequenties heeft voor in euro's aangegane verbintenissen. Met het oog daarop zal hieronder in paragraaf 3 worden uiteengezet hoe de Nederlandse rechter in het verleden is omgegaan met vergelijkbare vragen met betrekking tot de bepaling van de contractvaluta. ${ }^{16}$ Voor de goede orde merk ik in dit verband nog op dat de vraag welke valuta aard en/of omvang van de betrokken geldverbintenis bepaalt - welke valuta in obligatione en/of in computatione is -, dient te worden onderscheiden van de vraag in welke valuta de schuld in kwestie uiteindelijk kan worden voldaan - welke valuta in solutione is. ${ }^{17}$ Niettemin zal de wijze waarop de verschuldigde geldsom is uitgedrukt toch veelal bepalend zijn voor de manier waarop zij moet of kan worden betaald. Niet zelden lijkt de valuta van betaling in geschil, terwijl in werkelijkheid de valuta waarin de verbintenis is aangegaan ter discussie staat.

\section{Onzekerheid relevante rekeneenheid}

Het komt in de praktijk regelmatig voor dat niet geheel duidelijk is welke rekeneenheid aard en/of omvang van een geldschuld bepaalt. Denkbaar is bijvoorbeeld dat partijen hebben gecontracteerd in een valuta die door haar benaming tot meer dan één geldstelsel kan behoren. Men stelle zich voor dat een Amerikaanse onderneming een Canadese werknemer uitzendt naar Australië voor een salaris van \$ 5000 dollar per maand. Zijn hier Amerikaanse, Canadese of Australische dollars bedoeld? Het probleem kan zich ook voordoen bij verbintenissen tot schadevergoeding wegens wanprestatie of onrechtmatige daad, in het bijzonder in die gevallen waarin de gelaedeerde partij kosten heeft gemaakt of een voordeel is misgelopen in een andere valuta dan die van zijn woonplaats c.q. het

16. Par. 3 is gebaseerd op en deels letterlijk ontleend aan de in Rank 1996, p. 102-111, opgenomen analyse van de rechtspraak, gepubliceerd in Contractenrecht VI (Rank), nrs. 2509a-2509c.

17. S. Royer, Verbintenissenrechtelijke aspecten van de geldontwaarding (preadvies Broederschap der Notarissen 1967), Den Haag: Broederschap der Notarissen in Nederland 1967, p. 18. Zie voor de Nederlandse regels inzake de betaling van verbintenissen in vreemde valuta: art. 6:121-126 BW. centrum van zijn economische verrichtingen. Ten slotte is denkbaar dat de valuta waarin een schuld is uitgedrukt tussen het ontstaan van de verbintenis en het moment van betaling door een andere rekeneenheid wordt vervangen. Men denke aan de vervanging van de Nederlands-Indische gulden door de Indonesische roepia en aan de vraag die in dit artikel aan de orde is, te weten de vervanging van de euro door een nieuw te introduceren valuta in één of meer Eurolanden. In al deze gevallen zal, wanneer partijen het daarover niet eens kunnen worden, de relevante rekeneenheid door de rechter moeten worden vastgesteld. De vraag is aan de hand van welke criteria dit dient te geschieden. In dit verband lijkt het dienstig om - in navolging van F.A. Mann ${ }^{18}$ - te onderscheiden tussen gevallen waarin van meet af aan onduidelijk is in welke rekeneenheid een verbintenis luidt en situaties waarin deze onduidelijkheid eerst na het ontstaan van de verbintenis is opgetreden.

\subsection{Initiële onzekerheid relevante rekeneenheid}

In het geval dat van meet af aan onduidelijk is in welke rekeneenheid de verbintenis luidt, kan weer worden onderscheiden tussen enerzijds gevallen betreffende verbintenissen tot betaling van een bepaalde, gefixeerde geldsom, bijvoorbeeld een verbintenis tot terugbetaling van een lening, en anderzijds gevallen betreffende verbintenissen tot schadevergoeding wegens wanprestatie of onrechtmatige daad. Bij verbintenissen van de eerste soort hebben partijen zelf voor een bepaalde valuta geopteerd, maar kennelijk op onduidelijke wijze. Bij verbintenissen tot schadevergoeding zal er veelal van een keuze van partijen voor een bepaalde valuta geen sprake zijn geweest, en worden partijen geconfronteerd met de situatie dat de schade in een bepaalde valuta dient te worden begroot. Bestaat de taak van de rechter in het eerste geval in het interpreteren van een overeenkomst van partijen, in het tweede geval bestaat zij veeleer in een zelfstandig vaststellen van de schade die de gelaedeerde partij heeft geleden. ${ }^{19}$

Uit de jurisprudentie blijkt dat in het kader van het beantwoorden van de vraag in welke valuta een geldverbintenis luidt bij verbintenissen tot betaling van een bepaalde geldsom rekening wordt gehouden met tal van factoren, waarvan de voornaamste zijn de aard van de transactie, de nationaliteit van partijen en hun woon- of vestigingsplaats, de plaats van de contractsluiting, de plaats waar de betaling moet geschieden en de overeengekomen wijze van betaling, en - bij geldleen de valuta waarin de leensom is verstrekt. ${ }^{20}$ Gelet wordt op de totale context van de overeenkomst. Daarbij wordt uiteindelijk steeds gekozen voor de valuta van het land waarmee het contract het nauwst is verbonden. Het spreekt vanzelf dat de hier bedoelde benaderingswijze niet altijd voor alle partijen

18. Mann 1982, p. 220-221; Proctor 2005, p. 107-108.

19. Vgl. Mann 1982 , p. 222, die in dit verband onderscheidt tussen gevallen van 'fixed indebtedness' en gevallen van 'unforeseen liability', en Proctor 2005, p. 108, die onderscheidt tussen 'liquidated sums' en 'unliquidated claims'.

20. Zie de rechtspraak vermeld in Contractenrecht VI (Rank), nrs. 2509a-2509b. Vgl. ook Mann 1982, p. 224-225. 


\section{Maandblad}

Vermogensrecht

even prettig hoeft uit te pakken. Illustratief zijn in dit opzicht de zogenaamde Indische valutageschillen. Het ging daarin steeds om de vraag of een in het voormalige Nederlands-Indië in guldens aangegane overeenkomst de Nederlandse dan wel de Nederlands-Indische gulden tot rekeneenheid had. Deze vraag is in de rechtspraak telkens in laatstgenoemde zin beantwoord, als gevolg waarvan de crediteur uiteindelijk enkel aanspraak kon maken op het nominale bedrag van de overeenkomst in (ten opzichte van de Nederlandse gulden gedeprecieerde) Indonesische roepia's. ${ }^{21}$

Bij verbintenissen tot betaling van een geldsom bij wijze van schadevergoeding wegens wanprestatie of onrechtmatige daad is de rechtspraak niet eensluidend. Verschillen treden met name aan de dag als het gaat om situaties waarin de crediteur kosten heeft gemaakt of een voordeel is misgelopen in een andere valuta dan die van zijn woonplaats c.q. het centrum van zijn economische verrichtingen. Soms oordeelt de rechter dat de schade moet worden berekend in de valuta waarin de kosten zijn gemaakt of het voordeel zou zijn genoten. In andere gevallen evenwel wordt de eigen valuta van de crediteur bepalend geacht. Berekening van de schade geschiedt in dit geval aan de hand van de omrekeningskoers van het tijdstip waarop de kosten zijn gemaakt of het voordeel getoucheerd zou zijn. ${ }^{22}$

\subsection{Latere onzekerheid relevante rekeneenheid}

Moeilijker is de situatie waarin eerst ná het ontstaan van de verbintenis onduidelijkheid optreedt over de valuta waarin de verbintenis luidt en dus uiteindelijk moet worden voldaan, welke situatie het onderwerp van dit artikel vormt. Denkbaar is allereerst dat er sprake is van een beperking van de territoriale reikwijdte van het geldstelsel waartoe de gebruikte valuta behoort. Dit kan het gevolg zijn van zowel de introductie in het desbetreffende gebied van een nieuw gecreëerde valuta als het van kracht worden aldaar van een van elders afkomstige rekeneenheid. Een voorbeeld van het eerste is de creatie in 1986 van een eigen munt door het eiland Aruba ten koste van de positie van de Nederlands-Antilliaanse gulden. Een voorbeeld van het tweede is de invoering van de Roemeense lei in 1919 in gebieden die in 1914 nog tot Oostenrijk-Hongarije behoorden, maar na de Eerste Wereldoorlog aan Roemenië werden toegewezen. Een andere mogelijkheid is dat de gebruikte rekeneenheid ophoudt te bestaan. Dit kan in de eerste plaats gebeuren doordat het betreffende geldstelsel in twee of meer afzonderlijke systemen wordt opgelost. Men denke aan de invoering in 1949 van een nieuwe munt door elk van de beide Duitslanden - in alle twee de staten D-mark genoemd in plaats van de Reichsmark. Mogelijk is echter ook dat voor

21. Zie de jurisprudentie vermeld in Contractenrecht VI (Rank), nrs. $2509 \mathrm{~b}$ en 2521 . Vgl. ook D. van Eck, Juridische aspecten van geld, met name in het vroegere Nederlands-Indië, Deventer: Kluwer 1970, p. 211-213, die stelling neemt tegen de door de rechtspraak gehuldigde opvatting dat er te allen tijde een afzonderlijke Nederlands-Indische gulden heeft bestaan en (op goede gronden) verdedigt (p. 106-158) dat er, althans voor de Tweede Wereldoorlog, sprake was van één (Nederlandse) gulden.

22. Zie de rechtspraak vermeld in Contractenrecht VI (Rank), nrs. 2509c en $2509 \mathrm{~b}$ het bestaande stelsel een ander stelsel in de plaats treedt. Dit laatste heeft zich vooral voorgedaan in de sfeer van de dekolonisatie. Men denke wederom aan de vervanging van de Nederlands-Indische gulden door de Indonesische roepia, na de dekolonisatie van Indonesië. Van totale substitutie van een valuta door een andere kan voorts sprake zijn bij hervorming van het nationale geldstelsel. In dit verband kan worden gewezen op de vervanging van de oude Franse frank door de nieuwe in 1958.

Rechtspraak, althans voor wat betreft het Nederlandse recht, is er tot dusverre alleen met betrekking tot de situatie dat het ene geldstelsel door het andere wordt vervangen. In deze gevallen wordt het bedrag van de verbintenis zoals dat in de oorspronkelijke rekeneenheid luidt, omgezet in een bedrag in de nieuwe munt, waarbij wordt omgerekend volgens de bij de invoering van de nieuwe munt vastgestelde koers. ${ }^{23}$ Deze benadering is in overeenstemming met het in art. 1:111 van het Burgerlijk Wetboek (BW) neergelegde nominaliteitsbeginsel, volgens hetwelk een geldschuld in beginsel naar haar nominale bedrag moet worden voldaan, en de regel dat het recht van het land van een valuta, de lex monetae, bepaalt waar een valuta voor staat.

De vraag is of deze benadering ook moet worden gevolgd als een valuta terrein aan een andere valuta heeft moeten prijsgeven, maar op zichzelf wel blijft voortbestaan. Het ligt wat mij betreft in de rede dat in een dergelijk geval eerst aan de hand van de regels die de rechtspraak heeft ontwikkeld voor initiële onzekerheden ter zake van de relevante rekeneenheid wordt vastgesteld welke valuta aard en/of omvang van de verbintenis bepaalt. Er is dan immers sprake van twee naast elkaar bestaande rekeneenheden, zodat conversie naar de nieuwe valuta niet vanzelfsprekend is. Stelt de rechter op basis van de eerdergenoemde factoren vast dat de relevante valuta wordt gevormd door de 'ingeperkte' rekeneenheid, dan is daarmee de kous af: de verbintenis luidde in deze rekeneenheid, luidt nog steeds in deze rekeneenheid en moet in beginsel gewoon in deze rekeneenheid worden betaald. Komt de rechter echter aan de hand van alle omstandigheden van het geval tot de conclusie dat de verbintenis geacht moet worden te luiden in de nieuw geïntroduceerde valuta, dan moet de verschuldigde som vervolgens in deze nieuwe valuta worden geconverteerd.

In het laatste geval rijst dan weer de vraag naar welke koers/ omrekenverhouding conversie in de nieuwe munt moet plaatsvinden. Ofschoon rechtspraak met betrekking tot deze situatie ontbreekt, ligt het wat mij betreft in de rede dat wordt omgerekend volgens de door het recht van het land van de nieuwe valuta bij de invoering van die nieuwe valuta vastgestelde koers, dit omdat het hier een wijziging van de valuta als zodanig betreft en daarmee een zaak die door de lex monetae wordt beheerst, en omdat, als eerder gezegd, deze benadering in over-

23. Zie de rechtspraak vermeld in Contractenrecht VI (Rank), nr. 2521. 
eenstemming is met het hier te lande geldende nominaliteitsbeginsel.

Ten slotte is er nog het geval dat een enkele geldeenheid in twee of meer afzonderlijke systemen wordt opgelost. Ook in deze situatie lijkt het het meest geïndiceerd dat eerst aan de hand van de voor initiële onzekerheden door de rechtspraak ontwikkelde regels wordt uitgemaakt welke valuta de relevante rekeneenheid is. Daarna zou moeten worden omgerekend volgens de door het recht van het land van die valuta bij de invoering vastgestelde koers. Het betreft hier een wijziging van de valuta als zodanig en daarmee een zaak die door de lex monetae wordt beheerst.

\section{Toepassing op de casus}

In het licht van het bovenstaande rijst nu de vraag hoe de thans voorliggende casus - waarin één of meer Eurolanden uit de euro treden of worden gezet en een nieuwe valuta invoeren, terwijl er wel een euro blijft voortbestaan - moet worden gekarakteriseerd. Uitgangspunt is daarbij een beoordeling door de Nederlandse rechter en de toepasselijkheid van Nederlands recht op de overeenkomst. Mijns inziens is er sprake van een gemengde casus: hij vertoont zowel overeenkomsten met de situatie waarin er sprake is van een beperking van de territoriale reikwijdte van een valuta, als met de situatie waarin een enkele geldeenheid in twee of meer afzonderlijke systemen wordt opgelost. Dat betekent mijns inziens dat na uittreding van een Euroland uit de euro steeds eerst door middel van interpretatie - waarbij alle feiten en omstandigheden een rol spelen - zal moeten worden vastgesteld door welke valuta aard en/of omvang van de door de Nederlandse leninggever in dat Euroland in euro's gedane uitzettingen worden beheerst. Bepaald zal immers moeten worden of dit de euro is of de nieuwe munt van het uitgetreden Euroland.

Hiervoor zullen bepalend zijn de in de rechtspraak ter zake van initiële onzekerheden ontwikkelde factoren, zoals de aard van de transactie, de nationaliteit van partijen, hun woon- of vestigingsplaats, de plaats van de contractsluiting, de plaats waar de betaling moet geschieden en, in het geval van geldleen, de valuta waarin de leensom is verstrekt. Van de hier genoemde factoren zullen de nationaliteit van partijen en hun woonof vestigingsplaats waarschijnlijk weinig toegevoegde waarde hebben. Zij zullen immers zowel wijzen op de euro als op de nieuwe valuta van het uittredende Euroland en elkaar in zoverre opheffen. De aard van de transactie - een lening -, de plaats waar de (terug)betaling moet geschieden en de valuta waarin de leensom is verstrekt, wijzen op de euro als relevante rekeneenheid. Daarnaast zal in dit verband met name van belang zijn wat er in de voorwaarden van de betreffende lening staat. Het maakt daarbij verschil of daarin uitsluitend wordt gesproken van de euro als valuta der verbintenis of valuta van betaling, of dat er, bijvoorbeeld in het geval van een Italiaanse obligatie, sprake is van 'the legal currency of Italy, i.e. the Euro' of zelfs alleen maar van een verwijzing naar 'the legal currency of Italy'. De laatste omschrijvingen zouden een indicatie kun- nen zijn dat bedoeld is te verwijzen naar de valuta van Italië, welke dat dan ook op enig moment zal blijken te zijn, en niet noodzakelijkerwijs naar de euro. Hetzelfde doet zich voor bij langlopende obligaties die al dateren van vóór de introductie van de euro. De kans is groot dat in de voorwaarden van dergelijke obligaties wordt gerefereerd aan de destijds vigerende nationale valuta, in het voorbeeld van zojuist de lire, of dat er alleen maar wordt gesproken over de legal currency van het betreffende land. Ook dat zou een indicatie kunnen zijn dat de relevante rekeneenheid niet de euro is, maar de (nieuw ingevoerde) valuta van het uittredende Euroland.

Komt de rechter tot de conclusie dat de relevante rekeneenheid nog steeds de euro is, dan luidt de verbintenis nog steeds in euro's en moet zij in beginsel gewoon naar haar nominale bedrag in euro's worden betaald. Dit bedrag kan hoger uitvallen dan het tegen de conversiekoers bepaalde geredenomineerde bedrag in de nieuwe vervangende valuta. Denkbaar is immers dat deze nieuwe valuta na haar invoering ten opzichte van de euro in waarde is gedaald. Het is het aloude beginsel van 'pacta sunt servanda', van de bindende kracht van een overeenkomst, dat zich hier doet gelden. Beschikt de leningnemer niet over de benodigde euro's, dan zal hij deze moeten aanschaffen om aan zijn euroverbintenis te voldoen, dit tegen de voor de leninggever geldende aankoopkoers van de dag waarop de betaling plaatsvindt. ${ }^{24}$ Komt de rechter tot de conclusie dat de relevante rekeneenheid de nieuw geïntroduceerde valuta is, dan zal de verschuldigde som in deze nieuwe valuta moeten worden geconverteerd. Dat zal dan moeten geschieden conform de bij de invoering van de nieuwe valuta door het uittredende Euroland vastgestelde koers. Als deze nieuwe valuta na haar invoering ten opzichte van de euro in waarde is gedaald, kan dit tot gevolg hebben dat het te betalen bedrag lager zal uitvallen dan wanneer de vordering in euro's zou zijn gebleven. Een ander gevolg van redenominatie zou kunnen zijn dat de leningnemer de mogelijkheid verliest om zijn schuld uit hoofde van de lening te verrekenen met een vordering op de leninggever, omdat schuld en vordering niet langer in dezelfde valuta betaalbaar zijn. ${ }^{25}$

Ook wanneer de uitkomst is dat de verbintenis nog steeds in euro's luidt, is het denkbaar dat de verbintenis uiteindelijk toch niet naar haar nominale bedrag in euro's zal worden voldaan. Dat een leningnemer zich met een beroep op redelijkheid en billijkheid, overmacht of onvoorziene omstandigheden zou kunnen onttrekken aan een verplichting tot betaling van een bedrag in euro's dat het geredenomineerde bedrag van de verbintenis te boven gaat, lijkt mij moeilijk voorstelbaar. Immers, op grond van art. 6:111 BW, het nominaliteitsbeginsel, dienen geldschulden naar hun rekenkundige grootte te

24. Zie voor de dag en de koers van omrekening naar Nederlands recht art. 6:124 jo. art. 6:126 BW.

25. TM bij art. 6:127 BW, Parl. Gesch. BW Boek 6, p. 492: ter zake van verbintenissen tot betaling van verschillende valuta is verrekening in beginsel alleen mogelijk indien de schuldenaar niet tot 'betaling effectief verplicht is (art. 6:121 BW) en derhalve de bevoegdheid heeft om in de hem verschuldigde valuta te voldoen. 
worden betaald. Wijzigingen in de koopkracht of koerswaarde hebben geen invloed op de omvang van het te betalen bedrag. ${ }^{26}$ Als eenmaal door de rechter is vastgesteld dat de verbintenis in euro's luidt, komen we ook niet meer toe aan de vraag of de redenominatieregels van het uittredende Euroland wellicht zouden moeten worden aangemerkt als bepalingen van bijzonder dwingend recht van het uittredende Euroland in de zin van art. 9 Rome I, waaraan te allen tijde voorrang zou moeten worden geven. Denkbaar is wel dat de leningnemer een beroep op overmacht of onvoorziene omstandigheden toekomt als hij door in euro's te betalen deviezenbepalingen van het uittredende Euroland zou overtreden of anderszins in strijd zou handelen met voor hem geldende wetgeving. ${ }^{27}$ Voorts zal een leninggever die over een in euro's luidende executoriale titel van de Nederlandse rechter beschikt niet altijd het hem verschuldigde bij de executie kunnen opeisen in euro's. Executie in euro's zal mogelijk zijn als de leningnemer vermogensbestanddelen in Nederland aanhoudt waarop de leninggever zich kan verhalen. Bevinden de vermogensbestanddelen van de leningnemer zich echter in het uittredende Euroland, dan zal het vonnis van de Nederlandse rechter eerst dan ten laste van deze vermogensbestanddelen ten uitvoer kunnen worden gelegd, nadat op het vonnis een exequatur is verstrekt door de rechter van het uittredende Euroland, of nadat het vonnis door deze rechter is erkend overeenkomstig Brussel I-bis. Het ligt echter voor de hand dat deze rechter het exequatur niet zal verlenen en erkenning van het Nederlandse vonnis zal weigeren met het argument dat op deze manier de door dit land uitgevaardigde redenominatieregels zouden worden omzeild, en dat dit in strijd is met de openbare orde van het forum.

Wanneer de uitkomst is dat de verbintenis luidt in nieuw geïntroduceerde vervangende valuta, rijst evenzeer de vraag of de leningnemer zich met een beroep op redelijkheid en billijkheid, overmacht of onvoorziene omstandigheden aan zijn betalingsverplichting zal kunnen onttrekken. Ofschoon dit niet volstrekt is uitgesloten, lijkt de kans hierop minimaal. In dit geval brengt het nominaliteitsbeginsel immers mee dat het geredenomineerde bedrag in de nieuwe valuta moet worden betaald en dat de omvang van het te betalen bedrag wordt bepaald volgens de door het uittredende Euroland bij invoering van de nieuwe geldeenheid vastgestelde omrekeningskoers. Omgekeerd rijst de vraag of de leninggever wellicht een beroep op redelijkheid en billijkheid of onvoorziene omstandigheden zou kunnen doen, bijvoorbeeld om aanspraak te maken op een hoger bedrag of op schadevergoeding, ter com-

26. Rank 1996 , p. 115 e.v. en met name p. 128

27. Zie over de vraag of deviezenbeperkingen overmacht opleveren: De Serière 2012. Overeenkomsten die strijdig zijn met buitenlandse deviezenbepalingen zijn in Nederland niet afdwingbaar als de desbetreffende bepalingen zijn ingevoerd en worden gehandhaafd in overeenstemming met het IMF-Verdrag. Zie art. VIII sectie 2(b) lid 1 IMF-Verdrag. Uiteraard zullen deze deviezenbepalingen ook niet in strijd mogen zijn met het voor EU-lidstaten geldende verbod om onderling en in relatie tot derde landen restricties toe te passen ten aan zien van het kapitaal- en betalingsverkeer. pensatie van de door hem als gevolg van de waardedaling van de nieuwe valuta geleden koerswijzigingsschade. Naar het lijkt, is de kans daarop eveneens minimaal. Het nominaliteitsbeginsel brengt mee dat wijzigingen in de koopkracht of koerswaarde geen invloed hebben op de omvang van het te betalen bedrag (primaire werking) en de benadeelde geen recht geven op enige schadevergoeding (secundaire werking). Vergoeding van schade die de leninggever heeft geleden doordat de koers van het geld van de verbintenis zich na het intreden van verzuim van de schuldenaar ongunstig heeft ontwikkeld ten opzichte van de euro, behoort op grond van art. 6:125 BW wel tot de mogelijkheden. Het is de situatie van verzuim die deze inbreuk op het nominaliteitsbeginsel rechtvaardigt. ${ }^{28}$

Ten slotte zij nog opgemerkt dat een aanwijzing door de rechter van de euro als relevante rekeneenheid alleen mogelijk zal zijn zolang deze munt nog in voldoende landen wordt gebruikt en daarmee zijn identiteit van euro behoudt. Op het moment dat de euro nog slechts in een gering aantal landen wordt gehanteerd, rijst de vraag of deze munt nog wel de munt is waarin partijen initieel hebben gecontracteerd. ${ }^{29}$ Dit heeft uiteraard consequenties voor de vraag of de euro nog als de relevante rekeneenheid kan worden aangemerkt waar het verbintenissen aangegaan in euro's met partijen gevestigd in uitgetreden Eurolanden betreft. Denkbaar is dat het valutamandje dat de euro eigenlijk is door het uittreden van een groot aantal Eurolanden een zodanig andere samenstelling krijgt dat niet geoordeeld kan worden dat de verbintenis luidt in euro's, althans niet in euro's zoals die op dat moment vigeren. Of dit ertoe zal leiden dat de rechter in een dergelijk geval per definitie voor de nieuw ingevoerde valuta van het uittredende land als relevante rekeneenheid zal opteren, of voor een synthetische euro als relevante rekeneenheid, die dezelfde samenstelling heeft als de euro waarin partijen destijds hebben gecontracteerd, valt niet zonder meer te zeggen. Het voert ook te ver om daar in het bestek van dit artikel op in te gaan.

\section{Maatregelen contractspartijen}

Duidelijk moge zijn dat het hier complexe materie betreft die nader onderzoek vergt. Duidelijk moge ook zijn dat de parameters waarbinnen rechters en partijen in dezen vrijelijk kunnen acteren nog niet vaststaan. De kans is groot dat er bij een ordelijk verlopende uittreding van één of meer Eurolanden uit de euro zijdens de EU zal worden voorzien in regelgeving om de continuïteit van contracten te waarborgen. In ieder geval zal er zijdens een uittredend Euroland worden voorzien in een omrekeningskoers tussen de euro en de nieuw geïntroduceerde valuta.

Wat marktpartijen en dus ook Nederlandse leninggevers nu reeds zouden kunnen doen, is het opnemen van bepalingen in nieuwe overeenkomsten met leningnemers in mogelijk uittre-

28. Zie W.A.K. Rank, Vergoeding van koerswijzigingsschade volgens NBW, WPNR 1986/5777-5778

29. Vgl. Hooft 2012 , p. 13 , en een aantal van de in noot 1 genoemde nieuwsbrieven, die in dit verband spreken van 'eurodesintegratie'. 
dende Eurolanden die helpen te voorkomen dat de verbintenis zal worden aangemerkt als een verbintenis luidende in de nieuw geïntroduceerde vervangende valuta. Te denken valt in dit verband primair aan bepalingen over de identiteit van de euro waarin wordt gecontracteerd. Daarnaast kan worden gedacht aan een forumkeuzebeding waarbij de Nederlandse rechter of de rechter van een ander EU-land dan het mogelijk uittredende Euroland als bevoegde rechter wordt aangewezen, aan een rechtskeuze voor Nederlands recht, althans voor een ander recht dan het recht van het mogelijk uittredende Euroland en aanwijzing van de woon- of vestigingsplaats van de leninggever als plaats van betaling. Voorts valt te denken aan het bedingen van zekerheidsrechten op vermogensbestanddelen van de leningnemer die buiten het mogelijk uittredende Euroland gesitueerd zijn, en het toekennen aan de leninggever van een verrekeningsbevoegdheid met betrekking tot in verschillende valuta's luidende verbintenissen. Ook kan worden gedacht aan bepalingen over omrekening en afronding voor het geval dat later geconcludeerd zou worden dat de relevante rekeneenheid niet de euro is, maar een daarvoor in de plaats getreden nieuwe valuta. Van nut zijn ook bepalingen die de leningnemer een beroep op redelijkheid en billijkheid, overmacht of onvoorziene omstandigheden ontzeggen en bepalingen die de leninggever op het punt van deze verweermiddelen accommoderen. Vanzelfsprekend zou het dienstig kunnen zijn om dergelijke bepalingen ook op te nemen in bestaande contracten, maar daarvoor is uiteraard wel de instemming van de wederpartij nodig. Bij standaardcontracten zoals obligaties zal dat in de praktijk nauwelijks realiseerbaar zijn.

\section{Conclusie}

Of een Nederlandse leninggever die uitzettingen heeft in euro's in een Euroland een valutarisico loopt als dat Euroland op enig moment (verplicht of vrijwillig) de eurozone verlaat en een nieuwe valuta invoert ter vervanging van de euro, hangt in belangrijke mate af van de vraag welke rekeneenheid als de contractvaluta moet worden aangemerkt. De rechtspraak die in het verleden in Nederland is gewezen met betrekking tot de bepaling van een contractvaluta is in dit verband een bruikbare inspiratiebron. Als de euro als de relevante rekeneenheid moet worden aangemerkt, zal de verbintenis in beginsel naar haar nominale bedrag in euro's moeten worden betaald. Als de nieuw ingevoerde valuta als de contractvaluta moet worden aangemerkt, zal de leninggever in de regel genoegen moeten nemen met een bedrag in de nieuw ingevoerde valuta, omgerekend tegen de bij de introductie van de nieuwe geldeenheid vastgestelde koers. Als deze valuta na haar invoering ten opzichte van de euro in waarde is gedaald, ontvangt de leninggever een lager bedrag en is er inderdaad sprake van een valutarisico. Dit makkt vaststelling van de relevante rekeneenheid door de rechter tot een cruciale aangelegenheid. De bevoegde rechter en het door deze rechter toe te passen conflictenrecht spelen in dit verband een niet te onderschatten rol. Omdat de rechter van het uittredende Euroland juridisch nauwelijks ruimte zal hebben om van de in zijn jurisdictie uitgevaardigde redenominatieregels af te wijken, is dan ook van belang dat de kwestie zo veel mogelijk buiten de rechtssfeer van het uittredende Euroland wordt gebracht, door de Nederlandse rechter of de rechter van een ander EU-land dan het uittredende Euroland aan te wijzen als de bevoegde rechter, door te kiezen voor Nederlands recht, althans voor een ander recht dan het recht van het mogelijk uittredende Euroland, en door aanwijzing van de woon- of vestigingsplaats van de leninggever als plaats van betaling. Daarnaast kan worden gedacht aan het opnemen van bepalingen die de continuïteit van de contracten zo veel mogelijk waarborgen, zoals bepalingen over de identiteit van de euro waarin wordt gecontracteerd en bepalingen over omrekening en afronding en verrekeningsbevoegdheid voor het geval dat later geconcludeerd wordt dat de relevante rekeneenheid niet de euro is, maar een daarvoor in de plaats getreden nieuwe valuta. 